March 2009, revised May 2010

\title{
Fear of fire sales, illiquidity seeking, and credit freezes
}

\author{
Douglas W. Diamond ${ }^{*} \quad$ Raghuram G. Rajan ${ }^{\dagger}$ \\ University of Chicago and NBER.
}

\begin{abstract}
Is there any need to "clean" up a banking system in the midst of a crisis, for instance, by closing some weak banks and forcing others to sell bad assets, or can one wait till the crisis is over? We argue that an "overhang" of impaired banks that may be forced to sell assets in the future can increase the private returns to holding illiquid assets sufficiently that weak banks have no interest in selling them. Anticipating a potential future fire sale, cash rich buyers have high expected returns to holding cash, which also reduces their incentive to lock up money in term loans. The potential for a worse fire sale than necessary, as well as the associated decline in credit origination, could make the crisis worse, which is one reason it may make sense to clean up the system even in the midst of the crisis. We discuss alternative ways of cleaning up the system, and the associated costs and benefits.

JEL codes: G21, G01, G28.
\end{abstract}

*Corresponding author. E-mail: d-diamond@uchicago.edu, phone: (773) 702-7283, fax: (773)8349134. Address: Douglas W. Diamond, University of Chicago Booth School of Business, 5807 South Woodlawn Avenue, Chicago, Illinois 60637.

${ }^{\dagger}$ Both authors are from the University of Chicago's Booth School of Business. We thank the Center for Research in Security Prices for research support. Rajan thanks the Initiative on Global Markets and the Stigler Center for research support. We thank anonymous referees, Viral Acharya, Franklin Allen, Denis Gromb, Larry Katz (the editor), Amit Seru, Jeremy Stein, and Robert Vishny for helpful discussions, as well as participants in seminars at the Federal Reserve Banks of Richmond and New York, Harvard University, Northwestern University, MIT, Princeton University, the University of Chicago, the University of Minnesota and Washington University for useful comments. 
A financial crisis, especially one that embeds fears of a potential future liquidity shock, where highly-levered financial institutions will be forced to sell illiquid assets at fire sale prices, can lead to a variety of seemingly perverse behaviors, including a halt in the sale of illiquid assets by potentially impaired institutions, an increased concentration of these institutions in assets exposed to liquidity risk, an increase in their short-term leverage, and a reduction in lending by healthy financial institutions. Indeed, owners of the highly-levered institutions could hold on to illiquid assets, causing such institutions to fail conditional on the liquidity shock, even when early sales could prevent them failing. We argue that interventions may be helpful in avoiding the worst consequences of the financial crisis, as well as in increasing the level of lending, and discuss the costs and benefits of alternative methods.

Let us start with a quick description of our model. Let a set of financial institutions with substantial short-term liabilities (henceforth called "banks”) have a significant quantity of assets that have a limited set of potential buyers. One example of such an asset is a mortgage-backed security which, in an environment where some mortgages have defaulted, can be valued accurately only by some specialized firms. Furthermore, let us assume that with some probability, the banks will need to realize cash quickly in the future. Such a need for liquidity may stem from unusual demands of the banks' customers, who draw on committed lines of credit or on their demandable deposits. It may also stem from panic, as depositors and customers, fearing a bank could fail, pull their deposits and accounts from the bank. Regardless of where the demand for liquidity comes from, it would force banks to sell assets or, equivalently, raise money, quickly. Given that the potential buyers for the bank's assets have limited resources, the asset would have to be sold at fire sale prices (as in Shleifer and Vishny (1992) and Allen and Gale (1994)).

One consequence of the fire sale is that it may depress asset values so much that the bank is insolvent. This may precipitate a run on the bank, which may cause more assets to be unloaded on the 
market, further depressing the price. Equally important, the returns to those who have liquid cash at such times can be extraordinarily high.

Folding back to today, the prospect of a future fire sale of the bank's asset can depress its current value - investors need to be enticed through a discount to buy the asset today, otherwise they have an incentive to hold back because of the prospect of buying the asset cheaper in the future. More generally, the high returns potentially available in the future to those who hold cash can cause them to demand a high return for parting with that cash today.

This is similar to standard dynamic asset pricing in financial markets and in markets with imperfect arbitrage such as Vayanos-Gromb (2002) or Kondor (2009), where future returns influence current required returns. But the elevated required rate of return now extends to the entire segment of the financial market that has the expertise to trade the security. If this segment also accounts for a significant fraction of the funding for potential new loans, the elevated required rate of return will be contagious and will depress lending. Moreover, the institutional overhang will affect lending not only by distressed banks but also by healthy potential lenders, a feature that distinguishes this explanation from those where the reluctance to lend is based on the poor health of either the bank or its potential borrowers. Note that the adverse effect of future illiquidity on current lending is absent in models where future asset values are low for other reasons, such as reduced future payoffs. In such cases, low asset values do not lead to an elevated rate of return to buyers.

More surprising though, the bank’s management, knowing that the bank could fail in some states in the future, do not have strong incentives to sell the illiquid asset today, even though such sales could save the bank. The reason is simple. By selling the asset today, the bank will raise cash that will bolster the value of its outstanding debt by making it safer. But in doing so, the bank will sacrifice the returns that it would get if the currently depressed value of the asset recovers. Since the states in which the depressed asset value recovers are precisely the states in which the bank survives, bank management would much rather prefer holding on to the illiquid assets and risking a fire sale and insolvency than 
selling the asset and ensuring its own stability in the future. Indeed, the bank would prefer to spend its cash to load up more on securities that are exposed to the liquidity risk because its private valuation for those securities exceeds the market's valuation. Banks become “illiquidity seekers”.

The ingredients of our model are illiquidity and its effects on pricing combined with the unwillingness of the potentially insolvent owners of equity to take actions equivalent to buying costly insurance. The intuition here is clearly analogous to the risk shifting motive in Jensen and Meckling (1976) and the underinvestment motive in Myers (1977), though the bank "shifts” risk or under invests in our model by refusing to sell an illiquid asset than by taking on, or not taking on, a project.

What is particularly interesting, though, is that the price risk of the illiquid asset stems directly from the bank’s liability structure, where demands for liquidity force a fire sale. This has two implications. First, unlike in earlier risk-shifting models, the risk is endogenous - different institutions holding the same asset would have different exposure to the risk of illiquidity depending on the maturity of their liabilities. Institutions with only long term liabilities would, for instance, have no risk exposure even while holding the same illiquid asset. Second, the risk associated with illiquidity is particularly attractive for a bank with high short-term leverage and limited liability, because when the adverse shock hits, the bank is likely to be insolvent. Put differently, illiquidity affects both asset and liability side in a bank, inducing a correlation that is absent in standard risk-shifting models. Illiquidity seeking is thus inherent in bank behavior. In addition, the resulting contagion in required rates of return, which could affect all kinds of activities requiring tying up cash, including lending, is a feature of the model that is not present in models of risk shifting stemming from reasons other than illiquidity.

Our point is very general. Any entity with illiquid assets and financed with short-term liabilities is exposed to liquidity risk. If the probability of an adverse shock to liquidity conditions, significant enough to cause it to become insolvent, goes up, limited liability gives it an incentive to expose itself more to the risk of illiquidity, either on the asset or liability side. Private and public interests diverge if a crisis becomes more probable. Since such decisions can alter overall liquidity conditions, multiple equilibria 
are also possible here. Also, illiquid institutions not only act as an overhang over the market, elevating required rates of return, but will also risk future insolvency by holding on to the assets, further elevating required returns. Thus, there is an inherent source of adverse feedback in any financial crisis, which is why cleaning up the financial system ex post may be an important contributor to recovery. At the same time, ex ante regulation to prevent an excessive build up of exposure to liquidity risk may also be warranted.

To unfreeze asset and credit markets, the authorities will have to move potentially illiquid assets held by distressed levered institutions into safer hands. They could force their timely sale, which effectively make the distressed institutions purchase insurance against the risk of illiquidity. They could also increase the capacity of potential buyers to buy those assets or remove the overhang of distressed institutions by recapitalizing them. By stabilizing the financial system and eliminating the possibility of fire sales, the authorities can avoid inefficient runs, and also eliminate the potential for high returns to be made by preserving liquidity for the future, thus increasing lending today.

In section I, we present the model. In section II, we examine the sources of illiquidity; in section III we explore extensions to the model to show how the possibility of a market freeze is general. In section IV we explore the effects of several government interventions, especially forced sales. In section $\mathrm{V}$, we relate the paper to the literature. We then conclude.

\section{The Model}

We will present the model in two steps: First, we will present a stripped down version which makes the basic point about the private incentive to retain exposure to liquidity risk. Later, we will present a more detailed extension that endogenizes prices.

A set of identical banks at date 0 each owns financial assets (for example, mortgage backed securities) that will be worth $Z$ at date 2 . The bank is financed with demand deposits (or overnight paper) 
of face value $D$, with $Z>D .{ }^{1}$ Therefore, the bank is solvent in the long run. For now assume each bank has a local monopoly on financing and can raise a fixed quantity of deposits if it pays an interest rate of 0 (we discuss other motivations for the bank's fixed cost of raising deposits, including deposit insurance or possible anticipated government bailouts of depositors in section II). Depositors can demand repayment at date 1 or date 2. Everyone is risk neutral, in the sense that all evaluate the future payoffs on their investments by their expected value. We ignore discounting of future cash flows. We assume until section III that $\mathrm{Z}$ is a constant, which means that the assets are not risky when held to maturity. The model's primary implications are clear in this simple setting.

At date 1 , banks face a common liquidity shock with probability $q$, where a fraction $f$ of their depositors withdraw. We will be more explicit about the sources of this shock later. Depositors demand cash (they cannot trade in the financial asset market and will not accept the asset in lieu of $\operatorname{cash}^{2}$ ). The bank will have to sell some of its asset for cash to meet this liquidity demand. The bank can raise money in anticipation of the shock by selling assets at date 0 for $P_{0}$ per unit of date- 2 face value, or it can sell assets, after the shock has been realized at date 1 , for $P_{1}$ per unit of date- 2 face value. Note that if the liquidity shock does not hit at date 1 , the bank will not part with the asset at that date for a per unit price less than 1.

Prices that buyers are willing to pay for the illiquid financial asset.

We will describe how the price that buyers are willing to pay at date 0 is determined, given the date-1 price. Let us assume there are buyers who are not subject to liquidity shocks (such as banks with

\footnotetext{
${ }^{1}$ Calomiris and Kahn (1991) offer a rationale for why firms may be financed with short term demandable debt and Diamond and Rajan (2001) argue why this may be an especially appropriate form of financing for a financial intermediary like a bank in a world where aggregate liquidity shocks are low probability (while being less appropriate for industrial firms).

${ }^{2}$ Depositors could be thought of as unsophisticated and hence unable to accept or trade mortgage backed securities or bank loans.
} 
more liquid assets or longer term liabilities, private equity, or Warren Buffet) who can buy at either date paying cash. The buyer is indifferent between buying at either date if the price gives him the same expected date 2 payoff per dollar spent, so long as the return is greater than the return on cash (so $P_{0} \leq 1$ and $P_{1} \leq 1$ ). If he buys at date 0 , he gets $\frac{1}{P_{0}}$ at date 2 , while if he holds on to the dollar to buy the asset at date 1 , he will get $\frac{1}{P_{1}}$ at date 2 if the liquidity shock hits at date 1 , and 1 at date 2 if it does not. Therefore, the date- 0 bid price of the buyer solves $\frac{1}{P_{0}}=q \frac{1}{P_{1}}+(1-q)$, or

$$
P_{0}^{b i d}=\frac{1}{q \frac{1}{P_{1}}+(1-q)}
$$

We will now determine the price that banks are willing to sell for at date 0 , given the date- 1 price, first when the bank remains solvent when the liquidity shock hits and second, when it becomes insolvent upon the shock but has limited liability. We will show that trading can dry up at date 0 in the latter case.

Reservation prices when banks are solvent given the shock

Now consider the always solvent bank's decision on when to sell. If the bank postpones any sale until after the shock has hit at date 1 , it will have to sell a fraction $\eta_{1}$ of the asset such that $\eta_{1} Z P_{1}=f D$, or $\eta_{1}=\frac{f D}{Z P_{1}}$. If it is solvent, $\eta_{1} \leq 1$, and it can raise the necessary amounts to pay withdrawing depositors and the depositors who stay till date 2 . The date 0 expected value of the payoff from selling at date 1 with probability $q$ is $q\left[\left(1-\eta_{1}\right) Z-(1-f) D\right]+(1-q)[Z-D]$, which on substituting for $\eta_{1}$ simplifies to $Z-D-q f D\left(\frac{1}{P_{1}}-1\right)$ 
In words, the bank foregoes an implicit return of $\left(\frac{1}{P_{1}}-1\right)$ for every dollar of asset it sells, and it sells $f D$ dollars worth, so its expected "illiquidity" cost whenever it has to sell at date 1 for a price $P_{1}<1$, which happens with probability $q$, is $q f D\left(\frac{1}{P_{1}}-1\right)$. Alternatively, the bank can sell at date 0 for $P_{0}$ and hold cash from date 0 to 1 , to cover the case where it needs liquidity. If it sells early at date 0 , it must sell a fraction of the asset given by $\eta_{0}=\frac{f D}{Z P_{0}}$. The bank's payoff from selling just enough to meet the liquidity need is (note that with probability $q$ the proceeds of sale of the fraction $\eta_{0}$ of the asset exactly pay off the $f D$ of deposits) $q\left[\left(1-\eta_{0}\right) Z-(1-f) D\right]+(1-q)\left[\left(1-\eta_{0}\right) Z+\eta_{0} P_{0} Z-D\right]$, which on substituting $\eta_{0}=\frac{f D}{Z P_{0}}$ simplifies to $Z-D-f D\left(\frac{1}{P_{0}}-1\right)$. That is, by selling at date 0 , the bank will forego the implicit return of $\left(\frac{1}{P_{0}}-1\right)$ on $f D$ dollars of assets with certainty.

The bank is indifferent between selling at date 0 and date 1 when $f D\left(1-\frac{1}{P_{0}}\right)=q f D\left(1-\frac{1}{P_{1}}\right)$ or

$$
P_{0}^{A s k}=\frac{1}{q \frac{1}{P_{1}}+(1-q)}
$$

This is also the bid price (see (1.1)), so both buyers and sellers are willing to trade on both dates so long as the date 0 price bears this relationship to the (yet-to-be-determined) date 1 price.

Note that we do not model any idiosyncratic reason for either buyer or seller to trade at date 0 as opposed to at date 1 . If we did, there would be active trading on both dates. 


\section{Limited Liability, Fire sales, and No Trade}

We assumed above that the bank was solvent when it had to sell to meet the liquidity shock. What if the bank becomes insolvent conditional on the liquidity shock at date 1 , and the banker has limited liability? Clearly, the banker would never sell at date 0 if he would fail at date 1 conditional on the shock, even after selling. The intuition is simple. The banker, in maximizing the value of equity, will want to maximize the value of the bank's assets conditional on survival. Since the bank survives only in the state with no liquidity shock, and because the asset pays off most when the banker holds it to maturity rather than if he sells it prematurely for a discounted price $P_{0}<1$, the banker prefers to hold the asset rather than sell it.

Now consider the case where the bank survives conditional on the date- 1 liquidity shock if it sells some assets at date 0 for $P_{0}$ but it fails at date 1 if it has not sold assets previously. ${ }^{3}$ The bank is willing to sell at $P_{0}^{a s k}$ at date 0 if the price allows it to avoid failure and

if $Z-D-\left(\frac{1}{P_{0}^{a s k}}-1\right) f D \geq(1-q)(Z-D)$, where the right hand is the bank's expected payoff with no asset sales, given it fails conditional on the liquidity shock hitting. Simplifying, we get

$$
P_{0}^{\text {Ask }} \geq \frac{1}{1+q\left(\frac{Z-D}{f D}\right)} \text {. We also know that given the price } P_{1} \text {, buyers are willing to pay }
$$

$P_{0}^{b i d}=\frac{1}{1+q\left(\frac{1}{P_{1}}-1\right)}$. The bid price is less than the ask, that is, no asset is offered for sale at prevailing

prices at date 0 if $\frac{1}{P_{1}}-1>\frac{Z-D}{f D}$. Simplifying, this condition is $f D>P_{1}[Z-(1-f) D]$, which is

\footnotetext{
${ }^{3}$ We can allow the bank debt to be bailed out by the deposit insurance corporation, so long as the banker/equity is wiped out (see later).
} 
satisfied if the bank has not sold assets at date 0 and is insolvent conditional on the liquidity shock at date 1. We have

Proposition 1: If the bank is insolvent at date 1 conditional on the liquidity shock and not having sold assets, it will never sell the asset at the bid price at date 0, even if by doing so it could remain solvent. No trade will take place for the asset at date 0.

In sum, so long as the "fire sale" price of the asset is so low at date 1 so as to drive the bank into insolvency, and the date 0 price reflects that future fire sale price, there will be no trade at date 0 - the market will freeze up. Intuitively, even if the banker could avoid failure at date 1 by selling at date 0 , he will be making a transfer to the depositors in the state of the liquidity shock (from value he would have enjoyed if he held the asset to maturity in the state with no liquidity shock). Limited liability allows him to avoid having to make this transfer. Since the date- 0 ask price when the bank is always solvent is exactly equal to the bid price, the date- 0 ask price, if the bank is insolvent conditional on the shock and enjoys limited liability, has to be higher for the selling bank to be indifferent between selling and not. Hence no trade will occur.

The underlying intuition is a combination of an aggregate liquidity shortage leading to fire sale prices (Allen and Gale (2004), Diamond and Rajan (2005)), and risk shifting (Jensen and Meckling (1976)) or underinvestment (Myers (1977)). The banker focuses on the value he will get conditional on the bank surviving. Rather than selling at the date-0 illiquid value, which transfers some of the value of the proceeds to the depositors (akin to the Myers debt overhang problem), he would rather focus on preserving value in the survival states by holding the illiquid asset to maturity (akin to the Jensen and Meckling risk shifting problem). The banker is unwilling to sell the assets at date 0 because he will be giving up the option to put the assets to the debt holders at a low price conditional on the liquidity shock or put differently, he will be paying for insurance against default in illiquid states without benefiting enormously from surviving in those states. 
Interestingly, the price risk associated with the illiquid asset stems directly from the bank’s liability structure, because demands from depositors for liquidity force a fire sale. Unlike in earlier riskshifting models, therefore, the risk is endogenous - different institutions holding the same asset would have different exposure to risk depending on the maturity of their liabilities. Institutions with only long term liabilities would, for instance, have no risk of illiquidity even while holding the same illiquid asset. Moreover, a bank with high short-term leverage and limited liability will see unlevered institutions in the market as paying too low a price to take on liquidity risk (or, equivalently, willing to offload it too cheaply), because they do not have the put option banks have. Therefore, highly levered banks will be unwilling to sell assets exposed to the risk. Put differently, illiquidity affects both asset and liability side in a bank, inducing a correlation that is absent in standard risk-shifting models. Indeed, if any bank is levered enough, far from selling illiquid assets, it will want to use any cash it has to buy illiquid assets from unlevered entities, so as to “double-up” on its bets.

Note that from the banker's perspective, when the bank holds a single asset, a sale of assets is equivalent to a sale of stock for cash. For the same reason that the bank will not sell assets for cash, it will not sell stock for cash given the prevailing prices in the market place. This is a form of underinvestment (Myers (1977), Ivashina and Scharfstein (2008)) whereby the bank will not issue stock because of the value transfer that goes to debt in states of insolvency, but it stems not from uncertain fundamental values but from the potentially low future (and low current) fire sale prices at which illiquid assets will have to be sold. ${ }^{4}$

In sum then, as expectations of date-1 liquidity fall so that the bank is insolvent conditional on the future shock, date-0 trading spontaneously dries up. Our model suggests then that distressed banks hold

\footnotetext{
${ }^{4}$ An oft mentioned rationale for why banks hold on to illiquid assets rather than selling them is the notion that their prices will go up in expectation. Indeed, it is easily shown that the price of the asset does rise in expectation so that $P_{0}<q P_{1}+(1-q)$. However, this is merely an artifact of Jensen's inequality and the need for returns to equalize over different horizons.
} 
on to illiquid assets instead of selling them because they believe the price of the asset will be much higher in the future, conditional on their own survival. Indeed, they would want to buy more of the illiquid asset from unlevered entities if they had spare cash.

\section{The Sources of Illiquidity}

Thus far, we have not described how the price $P_{1}$ is determined Clearly, this is critical to our analysis, for without a low $P_{1}$ there would be no illiquidity or potential insolvency at date 1 , and no market freeze at date 0 . Let the weight of the potentially “illiquid” banks we have described so far be normalized to 1 . We will now distinguish between securities that can be sold and loans on the bank's portfolio that can be recalled but not sold. This will add more detail to our analysis, and will not qualitatively affect our previous analysis.

Let fraction $\beta$ of each bank's assets be composed of the financial security we have described so far. Let fraction $(1-\beta)$ of its assets be loans with face value $Z$ maturing at date 2 . We will assume these loans can be recalled by the bank at date 1 - borrowers will then have to liquidate projects to repay the bank, so as a short hand, we will say that banks liquidate loans. The bank's loan portfolio has differing liquidation values, with the range uniformly distributed between 0 and $\mathrm{Z}$, that is, loans can be liquidated for values ranging from nothing to full face value. The possibility of liquidating loans gives the bank an alternative source of cash, in addition to selling financial assets to buyers. We assume loans cannot be sold (they have little value in another lender's hands, because he has little ability to collect repayment).

Liquid buyers (private equity, hedge funds, and liquid banks) can purchase the financial asset at either date, and start with $\theta$ in cash at date 0 . Assume for simplicity that they are equity financed. Let these buyers also have the possibility of making term loans to industrial firms. If $R$ is the date- 2 return on a dollar lent at date 0 , let the available volume of loans returning greater than or equal to R be $I(R)$, with 
$I(1)=\bar{I}, I^{\prime}(R)<0, I^{\prime \prime}(R)>0$ when $R>1$. Loans made by liquid banks return nothing at date 1 , though at the cost of additional unneeded complexity, we could assume a somewhat higher date 1 return. Liquid buyers can store any excess funds at date 0 at a rate of 1 . The timeline is

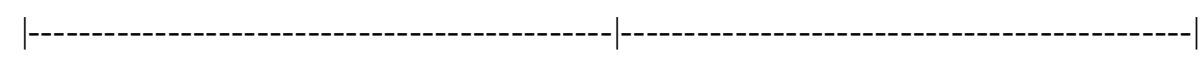

\begin{tabular}{|l|l|l|}
\hline \multicolumn{1}{|c|}{ Date 0 } & \multicolumn{1}{c|}{ Date 1 } & \multicolumn{1}{c|}{ Date 2 } \\
Illiquid bank sells securities \\
$\begin{array}{l}\text { (or not). Liquid buyers buy } \\
\text { securities, make loans, and } \\
\text { hold cash. }\end{array}$ & $\begin{array}{l}\text { Liquidity shock hits (or not) and } \\
\text { depositors withdraw from banks. Banks } \\
\text { decide loans they want to liquidate. Banks } \\
\text { sell securities and buyers buy with cash. }\end{array}$ & $\begin{array}{l}\text { Loans and securities pay off. } \\
\text { Banker consumes proceeds } \\
\text { after paying deposits. Buyers } \\
\text { consume. }\end{array}$ \\
\hline
\end{tabular}

Fire Sales and Lending

Let us now derive prices. If $\theta-\bar{I} \geq f D$, then liquidity is plentiful. All industrial projects are funded, and no loans are liquidated. The asset will trade for full face value $Z$, so $P_{0}=P_{1}=1$.

But if $\theta-\bar{I}<f D$, the asset will trade at a discount to face value. At date 0 , the implied interest rate on risk free term loans has to match the return from buying the financial asset, that is, $\frac{1}{P_{0}}$. This means the amount lent by potential buyers at date 0 is $I\left(\frac{1}{P_{0}}\right)$. Intuitively, the long-term effective interest rate, and thus the extent of long-term lending, is determined by the discounted price of illiquid financial assets in the market - that reflects the opportunity cost of locking up cash in loans. $I^{\prime}$ also therefore reflects how the supply curve of liquidity provided by buyers varies with the effective interest rate.

Similarly, conditional on the liquidity shock at date 1 , the illiquid bank will liquidate any loan at date 1 with liquidation value greater than $P_{1} Z$ before it sells any securities for $P_{1}$. Provided the bank does not have to sell all its securities to meet the demand from depositors (it is at an interior), the implied 
interest rate the bank will use to judge whether to continue loans at date 1 is $\frac{1}{P_{1}}$, so the date- 1 price of securities, through the bank's first order condition, effectively determines the amount of date-1 loans recalled. The total value of cash generated from recalled loans is $\frac{(1-\beta)}{Z} \int_{P_{1} Z}^{Z} x d x=(1-\beta) \frac{Z}{2}\left(1-\left(P_{1}\right)^{2}\right)$. If the financial asset trades at a discount to face value conditional on the liquidity shock (so the interest rate is positive), only withdrawing depositors will hold cash (all who have expertise in the financial asset will want to hold it instead of cash). Therefore, cash supplied from loan liquidation and from buyers will equal cash demanded by depositors so that

$$
(1-\beta) \frac{Z}{2}\left(1-\left(P_{1}\right)^{2}\right)+\left[\theta-I\left(\frac{1}{P_{0}}\right)\right]=f D
$$

Also, we know that in equilibrium, $P_{0}=\frac{1}{q \frac{1}{P_{1}}+(1-q)}$. Substituting in (1.3), we can solve for the single unknown, $P_{1}$, which is determined by the bank's need to recall enough loans to meet the aggregate demand for liquidity. The necessary condition for (1.3) to be the equation determining $P_{1}$ is that the bank be solvent, that is, it have enough value after date- 1 withdrawals to pay out depositors who stay till date 2 . This requires that $\beta\left(1-\eta_{1}\right) Z+(1-\beta) P_{1} Z \geq(1-f) D$. If withdrawals are met, $f D=(1-\beta) \frac{Z}{2}\left(1-\left(P_{1}\right)^{2}\right)+\beta \eta_{1} Z P_{1}$. Using this to substitute for $\eta_{1}$, the solvency condition is

$$
P_{1}\left[\beta Z+(1-\beta) P_{1} Z-(1-f) D\right]+\left[(1-\beta) \frac{Z}{2}\left(1-\left(P_{1}\right)^{2}\right)-f D\right] \geq 0
$$

The terms in the first set of square brackets on the left hand side of (1.4) sum up to the difference between the value of long term assets and un-withdrawn deposits, which are discounted to date 1 at price $P_{1}$, while 
the term in the second set of square brackets is the difference between cash realized from liquidated loans and cash withdrawn, a liquidity shortfall that will have to be made up by selling financial assets. So long as (1.4) is met, the bank will be solvent even if it sells more securities at date 0 (because $P_{0}>P_{1}$ ).

As $P_{1}$ falls, it becomes harder to meet the solvency constraint - asset illiquidity leads to insolvency as in Diamond and Rajan (2005). If the potential liquidity demand $f$ and bank debt $D$ are very high or the available cash liquidity net of industrial demand, $\theta-I$, low, so that (1.4) is not met, then the bank will be insolvent when the illiquidity shock hits and securities trading will cease at date 0 .

Lemma 1: (i) An increase in potential liquidity demand, $f$, or bank debt, $D$, as well as a decrease in the relative size of liquid entities, $\theta$, will lead to a lower current and future expected price of the long dated asset Z. (ii) An increase in the probability of the liquidity shock, $q$, will lead to a decrease in the date 0 price $P_{0}$ and an increase in the date 1 price $P_{1}$. (iii) If there is a $f=f^{R}$ at which all sales of the long dated asset $Z$ cease at date 0 , then ceteris paribus, there will be no sales for any $f>f^{R}$. If there is a $D=D^{R}$ at which all sales of the long dated asset $Z$ cease at date 0 , then ceteris paribus, there will be no sales for any $D>D^{R}$. If there is a $\theta=\theta^{R}$ at which all sales of the long dated asset $Z$ cease at date 0 , then ceteris paribus, there will be no sales for any $\theta<\theta^{R}$.

Proof: See Appendix.

The intuition behind Lemma 1 (i) is straightforward. Turning to lemma 1 (ii), an increase in the probability of the liquidity shock will make the returns to holding cash to buy assets at date 1 higher, so the date 0 price of the asset has to fall. In turn, however, this implies less lending, so more cash will be available to meet the liquidity demand, and the date 1 price of the asset will rise. Therefore the higher the probability of the liquidity shock, the greater the precautions the system takes against it, and less the chance of individual failure conditional on the shock. Lemma 1 (iii) suggests that as liquidity demand 
increases or supply decreases, there will eventually be a "sudden stop" in date 0 trading as banks become insolvent conditional on the liquidity shock.

Proposition 2: An increase in potential liquidity demand, $f$, the face value of bank deposits, $D$, or the probability of the liquidity shock, $q$, as well as a decrease in the relative size of liquid entities, $\theta$, will lead to a reduction in date-0 lending.

Proof: Lending increases in $P_{0} . P_{0}$ decreases in $f, D$, and $q$ and increases in $\theta$ from lemma 1 . Hence the proposition. Q.E.D.

As the returns to buying illiquid assets increases, date-0 lending shrinks. Indeed, if date-0 trading in the financial asset halts completely, liquid buyers may have plenty of cash on their balance sheet which they do not lend, in anticipation of buying assets cheaply at a date-1 fire sale (also see Acharya, Shin, and Yorulmazer (2009)). To the outsider politician, this may seem excessive caution; after all, the liquid buyers have no fear of liquidity shocks. Politicians may want to mandate more date-0 lending for the liquid buyer. However, the behavior of potential buyers could well be a rational choice as they demand a premium for locking up their money in term loans.

\section{Illiquid Banks}

We assumed thus far that the price of securities is high enough that the bank sells only some fraction of the securities it holds to attract all the available cash in the market, that is, $P_{1} \beta Z>\left[\theta-I\left(\frac{1}{P_{0}}\right)\right]$. The demand for liquidity could be so high that even if the bank sells all the securities it has for all the cash 
buyers have (so that the security price $P_{1}^{C}$ is such that $P_{1}^{C} \beta Z=\left[\theta-I\left(\frac{1}{P_{0}}\right)\right]$ ), the amount obtained from liquidating loans (down to those with liquidation value $P_{1}^{C}$ ) falls short of the amount demanded by depositors, that is, $\left[\theta-I\left(\frac{1}{P_{0}}\right)\right]+(1-\beta) \frac{Z}{2}\left(1-\left(P_{1}^{C}\right)^{2}\right)<f D$.

If the bank continued to hold all its securities to date 1 , it will now have to recall loans whose liquidation value per unit of face value liquidated is lower than $P_{1}^{C}$ so as to meet withdrawals. ${ }^{5}$ If $P_{1}$ solves (1.3), the solvent bank is now better off selling some of its securities at date 0 rather than waiting till date 1 and liquidating loans. ${ }^{6}$ Indeed, all banks will have this incentive, until the price of date-1 securities is pushed down to the $P_{1}$ that solves (1.3). Note that while individually banks will have the incentive to sell earlier, collectively they will not be better off since the cash in the market limits what they can get for securities. Indeed, by attempting to sell securities at date-0 for what the market will pay, the banks could collectively reduce their value considerably, perhaps even to the point of insolvency. We will not explore such adverse attempts to corner liquidity in what follows, leaving them to future research.

\section{Bank Runs and Inefficiency}

\footnotetext{
${ }^{5}$ If banks could accept deposits from liquid buyers at this point, (1.3) would continue to hold even without date-0 sales. We assume deposit markets are segmented and such deposits do not take place only to explore the situation where the security price is set purely by the cash available in the market, recognizing that there typically are other margins that also adjust.
}

${ }^{6}$ Intuitively, the bank's date-0 ask price when no securities are sold at date 0 is $P_{0}^{A s k}=\frac{1}{q \frac{1}{P_{1}}+(1-q)}$, reflecting the date-1 opportunity cost of not having liquidity, while the buyer bid price is larger at $P_{0}^{B i d}=\frac{1}{q \frac{1}{P_{1}^{C}}+(1-q)}$, reflecting the price of date- 1 securities. So the bank will sell at date 0 until prices are equalized. 
Our focus thus far has been on explaining why the market for specialized financial assets can freeze and how this affects other lending. We have ignored any efficiency consequences of bank insolvencies, fire sales, or credit contractions. Provided there are no externalities from lending (that is, no surplus generated by a borrower that the lender does not internalize), fire sales when banks are solvent do not produce inefficient outcomes. ${ }^{7}$ They are simply a way liquidity is obtained from buyers and transferred to those claimants on the bank who need liquidity.

However, insolvency will precipitate a run on the bank. This will cause the bank to sell all its securities for the available cash in the market (thus reducing their price, as well as date-0 lending), and to recall all its date-1 loans regardless of their liquidation value, a source of significant inefficiency.

\section{An Example}

Let the base case be $Z=2, \theta=0.3, f=0.58, q=0.2, \beta=0.5, I\left(1 / P_{0}\right)=0.3 * 1.2^{1-\left(\frac{1}{P_{0}}\right)}$. Given these parameters, $P_{0}=0.354, P_{1}=0.0988$ and the amount of date 0 lending is 0.215 . The bank could sell just $24 \%$ of its securities holdings at date 0 , not sell any securities at date 1 , and be solvent. Early sales therefore are a way to purchase liquidity insurance. However, if it does not sell any at date 0 , it will find it has to sell 86 percent of its securities portfolio at the depressed price conditional on just selling enough to meet the liquidity shock. It will become insolvent, be run, and will need to sell all its assets. Yet it prefers not to sell at date 0 because the expected value of equity is higher conditional on no sale than conditional on the date- 0 sale, for reasons we have explained.

In Figure 1, we plot date 0 and date 1 security prices as we vary the amount of available cash with liquid buyers, $\theta$. At levels of $\theta$ below 0.32 , the banks will fail conditional on the liquidity shock, and

\footnotetext{
${ }^{7}$ Our model has no such externalities, but they are present in Diamond and Rajan (2005).
} 
will be run. Securities prices are low and lending even lower. Interestingly, an increase in liquidity from 0.29 to 0.3 makes little difference in prices or lending because it does not alter the fact that the bank will be run, and that the date- 1 fire sale prices conditional on the shock will be very low, so date- 0 prices will be low. However, if enough liquidity is infused into the system so that the bank is not insolvent at date1, securities prices are considerably higher at date 1 and date 0 , and consequently, date- 0 lending (see Figure 2) jumps.

Key Assumptions of the Basic Model

It may be useful to discuss our key assumptions. They include the assumptions that lead to illiquidity, the liquidity shock, deposits not re-pricing, and the contagion to term lending.

\section{1) Sources of Illiquidity}

The key contractual element that exposes the financial institution to illiquidity is that short-term debt can be withdrawn (or committed lines of credit can be drawn down - see Kashyap, Rajan, and Stein (2002)) before the assets mature. If there was no possibility of needing to sell assets before date 2, then the market values of the assets would not be depressed by forced fire sales and as a result there would be no risk of insolvency. With no insolvency, banks would not seek illiquidity nor would the market freeze.

The assets are illiquid in our model because the set of (equally) informed buyers is limited and they have finite borrowing capacity (as in Shleifer and Vishny (1992)). ${ }^{8}$ Hence buying capacity, rather than asymmetry of information between buyers and sellers of assets, drives our results. Implicit here is the idea that potential buyers cannot raise funds and increase scale instantly. Of course, over time we would expect that if there were substantial quantities of illiquid assets, existing skilled buyers would raise more

\footnotetext{
${ }^{8}$ One reason is that any buyers outside the set of the skilled would find it hard to tell the few bad securities from the majority of good ones, and could well face a substantial lemons problem if they tried to buy. Another is that the asset requires active management that only the skilled can provide.
} 
funds and more entities would acquire the necessary skills. So illiquidity of this kind would, at best, be a medium term phenomenon.

\section{2) The Liquidity Shock}

We have referred to the bank's required need at date 1 of $f D$ of cash as a liquidity shock, without specifying the source. It could be a need by depositors for working capital for their own businesses during a period of limited liquidity, or represent a fear-based withdrawal by some (uninsured) depositors or other short-term creditors who come to doubt the bank's viability or the government's ability or willingness to protect bank creditors. One example is the loss of access to interbank loan markets where other banks anticipate future problems with the bank and prefer to collect before the bank fails or is closed (as in Smith (1991)). Diamond and Rajan (2005) provides a general equilibrium model of this type of run-based withdrawals stemming from a shortage of liquidity, stressing the two-way causality between illiquidity and insolvency.

\section{3) Deposits and Re-pricing}

We have assumed the bank's cost of funding does not vary with the market interest rate implied in the illiquid asset's price. Underlying this assumption is that bank depositors do not have the expertise to trade the illiquid asset, and as a result changes in the expected return offered in the illiquid secondary market do not necessarily force banks to increase the interest rates offered to depositors. We could relax this assumption without qualitatively affecting the basic results.

More important, we assume that when a bank subject to liquidity shocks sells assets early and reduces the default risk to depositors, the deposit rate does not fall. We justify this arguing banks have a local monopoly over deposits and depositors inelastically supply a fixed quantity of deposits at date 0 at the offered interest rate (normalized to 0) and do not demand additional compensation for greater default risk. 
A cost of debt capital that is relatively insensitive to default risk is an important driving force of the model.

More concretely, the lack of full adjustment of the bank's cost of funding to asset sales arises when one portion of bank debt (such as existing long-term debt as in Myers (1977), insured deposits, or shortterm debt which might, ex-post, end up being insured) is relatively insensitive to bank actions, while another portion of debt (such as overnight borrowing, uninsured demand deposits, and cash in brokerage accounts) is sensitive to the bank's health and susceptible to run. ${ }^{9}$ So, for example, if at least fraction $f$ of the deposits is short term debt, and there is enough value to pay off the short term debt, then the short term debt is potentially safe. Withdrawing depositors could obtain full face value when they withdraw at date 1 . However, if liquidity is in short supply (that is, $\theta-I<f D$ ), the value of the bank's assets may be so depleted at date 1 that the remaining short term debt also withdraws - if it renews, it will have to share firm value with the long term debt maturing at date 2, and there may not be enough to make it better off relative to withdrawing. Thus short term debt may be largely risk free at date 0 , yet precipitate insolvency at date 1 through its demand for liquidity. ${ }^{10}$

A final related motivation for the incomplete adjustment of a bank’s cost of short-term funding to its default risk is if lenders think there is a possibility, but not the certainty, of a bail out. In this case, the bank’s upfront cost of funding will not adjust fully to its true risk, but at a later date, lenders may run for their money (the liquidity shock) if they feel the government will not come through with support.

\footnotetext{
${ }^{9}$ The search for illiquidity and the resulting unwillingness to sell occurs even if all deposits are insured, as long as the bank's equity value is wiped out when the liquidity shock makes it insolvent.

${ }^{10}$ We say "largely risk free" because if short term debt were fully paid off, the bank would never fail at date 1 (though it might be insolvent when long term debt matures at date 2). We need some default on the short term debt so that payment on long term debt is accelerated and the bank is run at date 1 . The notion that short term debt could make itself whole through contingent actions thus precipitating wider consequences is in Diamond (1991) and Rajan and Winton (1995), as well as Brunnermeier and Oehmke (2009).
} 


\section{4) Initial conditions}

We have assumed that banks start out with no cash. In a situation where there is potentially severe illiquidity at date 1, banks do want to “double-up” on their illiquidity risk by spending all their cash acquiring illiquid securities. So one could imagine a stage of the game before the one we analyze where, as anticipation of the severity of the liquidity shock increases, banks spend their cash buying potentially illiquid securities. The more general point is there are "tipping” points, where once the anticipated price of the illiquid security is low enough conditional on the shock, banks will be willing to pay more for these securities than they are worth to unlevered market participants, and will attract them from the rest of the market, even while potentially reducing the market price further. ${ }^{11}$

We have assumed a two-period model, with no further bank "franchise value” (value earned by the bank after date 2, but only if it remains solvent). Clearly, future franchise value would increase the implied equity stake the banker has, and thus reduce the risk of insolvency and the associated incentives, but it does not change the fundamental character of the problem. If banks differ greatly in franchise value, then other things equal, those with a sufficiently high franchise value would sell assets at date 0 (to “de-lever”) and those with low franchise values would be willing buyers (and would be willing to pay more than the unlevered buyers that we describe in the model).

Finally, it is not surprising that some banks become so levered that they will be insolvent conditional on a liquidity shock. If liquidity crises are rare, financing with short-term debt will usually be quite safe. If the probability of such a crisis increases rapidly, banks will find themselves in the overhang position described in our model, and at such a time will become illiquidity seekers. Because illiquidity becomes pervasive across the spectrum of assets with a limited set of buyers, bank debt overhang due to

\footnotetext{
${ }^{11}$ This depends on whether the cash banks pay leaves the set of potential buyers into other uses or stays in that set.
} 
prospective illiquidity may be more likely than the more traditional debt overhang caused by heightened borrower credit risk.

\section{5) Contagion to Term Lending}

Term lending (as opposed to overnight lending) would be curtailed so long as such lending is done by either the illiquid banks or the potential buyers of their assets. In other words, it is because of the future high potential implied rate of return on illiquid assets that today's required rate of return on those assets is high, as is the required rate of return on any other activity such as lending that is undertaken by any financial firm that has access to this market. The spike in the required rate of return can spread even to institutions that have no capacity to buy the illiquid asset. For instance, some large banks may cut off client firms from borrowing, because they see better value in holding illiquid securities. These client firms may then approach smaller banks that do not operate in the illiquid asset market. These banks may nevertheless raise the interest rate they charge because of higher demand for their loans.

6) Smoother trade

In our model, banks refuse to sell at date 0 as soon as there is any possibility they might default. If there were some frictional reasons for trade (for example, some buyers are willing to buy at a slightly higher price than the bid price we calculate), then there would be some selling at date 0 if banks have a very low probability of insolvency (the benefits of trade would exceed the small value of the put foregone), but not if the probability becomes higher. If the chance of receiving a liquidity shock that causes insolvency varies across otherwise identical banks, we would see the extent of asset trade varying with the probability of the liquidity shock in a more continuous way. Consider the following extension.

\section{Extension 1: Heterogeneity in Exposure to the Shock}


Suppose the probability of the aggregate liquidity shock is $q$ as before, but conditional on a liquidity shock, each bank $i$ has a probability $\delta^{i} \leq 1$ of getting the shock. Assume further that the fraction of banks that get a shock, conditional on the shock occurring, is constant - there is no aggregate uncertainty conditional on the shock.

One might expect that banks with a lower anticipated exposure to the shock might require a higher price to sell at date 0 - after all, they are less likely to need liquidity. Simple algebra suggests (see web appendix), however, that if banks remain solvent given the shock, the probability of the shock does not affect the price they ask for the asset. As before, therefore, the bid and ask prices are identical when there is no insolvency. The intuition is interesting. The ask price at date 0 that we computed earlier in (1.2) fully compensated banks for the cost of selling early and having spare liquidity if the aggregate shock does not hit. In addition, the ability to reinvest spare date- 0 cash at the low security price $P_{1}$, if the aggregate shock hits but the individual shock does not, fully compensates a bank for having spare liquidity at date 0 . Intuitively, they can reverse the date- 0 sale at date 1 by buying securities at the distressed price $P_{1}$ at no expected cost. This is why the size of the idiosyncratic shock does not matter if banks are solvent. But if banks are insolvent if the idiosyncratic shock hits, $\delta^{i}$ does determine the size of the put option.

Proposition 3: If banks have differing exposure $\delta^{i}$ to the aggregate liquidity shock, the ask price does not vary with $\delta^{i}$ if banks are solvent conditional on the liquidity shock hitting them, but increases in $\delta^{i}$ if they are insolvent conditional on the shock hitting them.

Proof: See appendix. 
If there are reasons to trade at date 0 , as mentioned at the end of the previous section, then the banks with the lowest probability of receiving a liquidity shock will be the most willing to trade at date 0 . This has implications for government actions to eliminate a market freeze. We discuss this in section IV.

\section{Extension 2: Risky vs Illiquid Assets}

Thus far, we have assumed that the illiquid assets have a value $\mathrm{Z}$ with certainty. It is hard to imagine then why the asset is illiquid, since anyone with cash could buy the asset and hold it to maturity. In particular, there would be no cost to the authorities of liquidity intervention, as long as the market price per unit of face value is less than one.

One reason why the authorities could be reluctant to intervene is that the asset might require management (as with a bank loan), and the authorities may not have the capability. But this is not a plausible explanation for arm’s length mortgage backed securities. Another reason, and one we have relied on so far, is that only the specialist knows the value of the security or, equivalently, a fraction of the illiquid assets could be very poor in quality, so any casual buyer will end up with an adversely selected lot of securities (unless he buys the whole portfolio, which even the government may not have the funds to do). But a third reason, is possible fundamental uncertainty about the asset's value, which overlays (and is partly responsible) for its illiquidity. Consider now an asset whose value is uncertain, but is not illiquid.

Suppose the date 2 value is not $\mathrm{Z}$ with certainty, but is $\mathrm{Z}$ with probability $1-\pi$ and $P_{1} Z<Z$ with probably $\pi$. The uncertainty about $\mathrm{Z}$ is resolved on date 1 , implying that the date 1 value, $P_{1} Z$, is now low because date 2 payments are expected to be low. In other words, we replace the liquidity shock with a shock to fundamentals. In this case, the asset is liquid and the gross rate of return from buying it at the low value at date 1 is the normal expected rate of return (one each period). Of course, because the asset is risky, a bank that would fail if and only if the lower asset value were realized at date 1 might still ask for a price at date 0 that exceeds the fundamental value of the asset, because it values the option to 
shift risk to lenders, as in Allen and Gale (2000b). This would cause a similar trading freeze, especially pronounced for liquid assets with values that are highly correlated with bank solvency.

The ask price required by the risky bank would be the same as derived for the base case earlier if the probability of the low cash flow is the same as that of the liquidity shock. The bid price would be somewhat higher than the bid price we found earlier (because buyers require a gross rate of return of only 1 in the future, implying their bid would be the fundamental value of the asset, that is $\pi P_{1} Z+(1-\pi) Z$ ). Because the hurdle rate for new date-0 lending would not be elevated by expectations of future fire sales, lending by potential buyers is normal, that is $\theta-\bar{I}$ (and promises of injecting future liquidity would have no effect on current or future asset prices). To explain both a general credit freeze, including few new loans by healthy unlevered buyers, and a freeze in securities markets, the fear of fire sales rather than fundamental uncertainty is, we believe, a more relevant model. Moreover, a fluctuating demand for liquidity generates a high correlation between an illiquid asset's value and the bank's solvency, which causes both illiquidity seeking and a trading freeze. By contrast, a bank with risky but liquid assets would not be deterred from selling a risky asset that is not very correlated with the value of its total portfolio.

\section{Interventions}

Government authorities (the Treasury, regulators, or central banks) might consider intervening to eliminate the market freeze and even influence the market price of illiquid assets for several reasons.

(i) An intervention that reduces the fire sale pricing and runs can increase the flow of credit from potential buyers and sellers, both at date 0 (new loans) and at date 1 (reduce unnecessary liquidation of old loans).

(ii) The authorities may need a market price to help determine if the banks are solvent. When the long run value $Z$ of the asset is random, banks and expert buyers may know the value but 
regulators may not. In addition, regulators may not know the amount of available liquidity, $\theta$.

Therefore, useful valuation information can be obtained about both fundamental values and expected liquidity conditions by unfreezing the market. ${ }^{12}$

Possible interventions include forcing some distressed institutions to sell, paying enough to induce voluntary sales to the authorities, increasing the capacity and incentive of potential buyers to buy distressed assets, providing liquidity directly to banks, or removing the overhang of distressed institutions by recapitalizing or closing them. In any intervention, the authorities may be handicapped by not knowing the fundamental value of assets themselves. The authorities may be willing to overpay (relative to the private market) because they internalize the economy-wide positive spillovers from having a healthy, functioning, financial sector, or because they have offered guarantees to depositors. ${ }^{13}$ In what follows, we examine various interventions, ranked somewhat loosely on their cost to the authorities. We begin with a case where it is possible that authorities can save banks without involving any taxpayer funds by forcing banks to sell some securities at date 0 (though regulators need legal authority to compel these sales). We follow with voluntary purchases and liquidity interventions, both of which require government taxation authority to inject liquidity, but which may possibly avoid taxpayer losses. Finally we consider subsidized injections of capital, which require taxation authority and involve expected taxpayer losses. Diamond and Rajan (2005) analyze the costs of liquidity and capital interventions, in a related setting.

\section{Forced Date-0 Asset Sales}

\footnotetext{
${ }^{12}$ Note that illiquidity would depress the bid price below fundamentals, while the put option, stemming from both illiquidity and risky fundamentals, could elevate the ask price, even above fundamental value if the prime driver of the value of the put option is risk about fundamentals.

${ }^{13}$ The overpayment could take the form of rents needed to ensure incentive-compatibility for buyers that can acquire the asset on the regulators' behalf, subsidies to induce banks to sell and partly reveal the value of assets, or losses made in buying claims on the illiquid assets (that the authorities do not have great expertise in).
} 
The bank may be insolvent conditional on the shock if it holds on to the security and sells only at date 1 . If, however, it sold the security at date 0 , it would get a higher price and perhaps avoid default. To the extent that this reduces the number of banks that are run at date 1 and therefore dump all their securities into the market, it could also push up prices for the securities, and thus increase lending at both dates. Since banks that expect to fail conditional on the liquidity shock do not have an incentive to sell assets at date 0 at the price buyers are willing to pay, sales will have to be forced by the authorities.

Proposition 4: Let the bank be insolvent if it retains all its securities till date 1 so that (1.4) is violated.

(i) If there is an $\eta_{0}$ with $\eta_{0} \in(0,1]$ such that

$$
\begin{gathered}
(1-\beta) P_{1} Z . P_{1}+(1-\beta) \frac{Z}{2}\left(1-\left(P_{1}\right)^{2}\right)+\beta Z\left(\eta_{0} P_{0}+\left(1-\eta_{0}\right) P_{1}\right) \geq(1-f) D P_{1}+f D \\
\beta Z \eta_{0} P_{0} \leq\left[\theta-I\left(\frac{1}{P_{0}}\right)\right]
\end{gathered}
$$

then all the banks can be made fail-safe by requiring them to sell $\eta_{0}$ of their securities at date 0 .

Now let $\left|I^{\prime}\right|$ be small.

(ii) If there is no $\eta_{0}$ with $\eta_{0} \in(0,1]$ such that (1.5) and (1.6) are satisfied, then not all the banks can be saved through forced date-0 sales. The maximum fraction of banks that can be saved is given by $\gamma$, where $\gamma, P_{1}$, and $\eta_{0}$ solve

$$
\gamma \beta Z \eta_{0} P_{0}=\left[\theta-I\left(\frac{1}{P_{0}}\right)\right]
$$




$$
\begin{gathered}
(1-\gamma) \beta Z P_{1}+\gamma\left(f D-(1-\beta) \frac{Z}{2}\left(1-\left(P_{1}\right)^{2}\right)\right)=\left[\theta-I\left(\frac{1}{P_{0}}\right)\right] \\
(1-\beta) P_{1} Z \cdot P_{1}+(1-\beta) \frac{Z}{2}\left(1-\left(P_{1}\right)^{2}\right)+\beta Z\left(\eta_{0} P_{0}+\left(1-\eta_{0}\right) P_{1}\right)=(1-f) D P_{1}+f D
\end{gathered}
$$

(iii) If no feasible solution exists to (ii), then the banking system cannot be prevented from failing through securities sales at date 0.

(iv) If some banks can be saved from failing through securities sales at date 0 , both $P_{0}$ and $P_{1}$ are higher (relative to the situation where all banks fail conditional on the shock), as are date 0 and date 1 lending.

Proof: See appendix.

The reason a forced sale at date 0 could contribute to bank solvency conditional on the liquidity shock is that the sales price pools the value of the security across future states (buyers essentially provide the bank insurance). So the bank is worth more conditional on the liquidity shock if it sells at date 0 than it would be worth if it did not sell and got hit by the liquidity shock. Indeed, if banks are forced to sell the appropriate amount at date 0 , the price of the security conditional on the shock will also be higher because, with fewer failed banks, fewer securities are dumped on the market (recall that failing banks dump all their securities and liquidate all loans). This implies that the sale at date 0 also fetches a higher price. Of course, forced asset sales will not work if securities prices are so low that solvency cannot be assured or if the probability of the liquidity shock is high (so selling at date 0 does not add much insurance to the value).

Note that once forced sales at date 0 exhaust all the cash buyers have set aside to buy securities, further forced sales will reduce the price of the security. If $\left|I^{\prime}\right|$ is small, buyers will not set aside more 
funds to buy securities at date 0 , even when they see the date-0 price of forcibly sold securities falling. If so, forcing security sales at date 0 beyond the point that buyer cash is fully absorbed by securities, will reduce the value of banks and hurt their solvency. In such cases, the authorities will be better advised to focus on saving a subset of banks as in Proposition 4 (ii). Of course, if $\left|I^{\prime}\right|$ is high, forcing security sales at date 0 beyond the point that buyer cash is fully absorbed by securities will depress the date- 0 price of securities and make the date-0 returns to buying these securities much higher, thereby diverting liquidity from other parts of the system, including term lending. This may help banks but at a cost to lending.

In sum then, the authorities have to tread carefully when forcing sales. If there is plenty of cash $\theta$ available with buyers, or if the size of the anticipated liquidity shock $f D$ is small, forced date- 0 sales can avert bank runs contingent on the liquidity shock and the associated adverse spillovers. If cash is limited relative to the size of the shock, however, forced date- 0 sales can precipitate date- 0 bank failures even when there were none before.

\section{Voluntary Sales to the Authorities}

The authorities can force sales only when they have some legal or regulatory ability to coerce the bank. If a bank has to sell voluntarily, it will demand at least the ask price, which is above the private buyer's bid price. The authorities can offer to buy securities through a reverse auction so as to establish securities prices, keep the securities off market in an entity like the Resolution Trust Corporation, and prevent some bank failures. A reverse auction will provide a price, but if authorities are unsure of why banks do not sell (and do not know $q, \delta^{i}$, or $f$ ), it will not reveal the long-run value of the security, Z, to them. Four additional features of the reverse auction are clear.

(i) Unlike with a forced sale, the authorities will have to pay for the put option banks have, making this a costlier intervention. In addition to paying a higher price, the authorities must have the resources to make the purchase or subsidize private purchases. 
(ii) As Proposition 3 indicates, the banks with the lowest value of the put option (that is, the lowest exposure to the liquidity shock, and hence the safest) would agree to sell at the lowest price. Thus a substantial amount of money could be spent in cleaning up banks that do not provide much reduction in future fire sales, while the banks most in need of being cleaned up may not sell at the auction clearing price.

(iii) Conditional on agreeing to sell, a bank would want to sell all its securities, since at any price over the bid price, selling and reinvesting conditional on the liquidity shock beats holding to maturity. ${ }^{14}$ If these selling banks were banned from repurchasing the illiquid security if they did not receive a liquidity shock on date 1 , they would demand a higher price for parting with it at date 0 .

(iv) The price at which banks will sell will increase with the amount of money the authorities puts into purchasing assets - because the fewer the assets left with the banks after the reverse auction, the higher the date-1 price conditional on the liquidity shock (this is assuming that the cash the authorities put into purchasing is additional to that in the hands of private buyers). At the same time, the selling price will also approach the price private buyers will pay because a higher date-1 price will eliminate the possibility of failure and hence the seller's put option. Interestingly, therefore, government purchases can restart an illiquid private market at a higher price. Note that if date- 1 illiquidity is not the problem but the problem is low fundamentals, the price will not move regardless of the amount the government puts in.

\footnotetext{
${ }^{14}$ To see this, the value of selling at the date 0 bid price and reinvesting conditional on the liquidity shock at date 1 is $\frac{P_{0}}{P_{1}} q+P_{0}(1-q)=1 \quad$ when $P_{0}=P_{0}^{\text {Bid }}=\frac{1}{\frac{q}{P_{1}}+(1-q)}$
} 
Liquidity infusion 1: Lend to liquid buyers at date 0 or date 1.

An alternative to the government buying directly is for it to lend to liquid buyers at date 0 or date 1, thus augmenting $\theta$ and boosting prices (see lemma 1). Buyers certainly have the expertise to value the assets, the real issue being whether they have the incentives to use government financing in a reasonable way. Some rents/subsidies may have to be offered to them to get them to use their expertise on behalf of the government. To the extent that buyers get these subsidies only if they purchase assets, they may have an incentive to pay for the put options banks have, and get them to sell assets. The cost to the authorities here is augmented by the rents they have to pay the buyers. Depending on the details, which are beyond the scope of this paper, this cost could be above or below the costs of the reverse auction discussed above.

\section{Liquidity infusion 2: Lend to the banks at date 1}

Yet another alternative is for the authorities to lend freely at date 1 to the banks experiencing liquidity withdrawals. If the government could commit to do this on a sufficiently large scale, the date-1 fire sale would be eliminated as would be the date 0 market freeze. The taxpayer costs may well be very similar to those of purchasing directly in a reverse auction, or to providing loans to private purchasers to help them buy the illiquid asset. However, if regulators are unsure about the asset values, they would not know if they were providing liquidity or participating in a bail out. If the public believed, rightly or wrongly, that lending was a bail out, it might be unwilling to support it. As a result, it might be difficult for the authorities to commit to unconditional date- 1 liquidity support at date 0 , preventing them from ending the freeze. Also, unconditional support could increase the incentive to become illiquid in the first place as in Diamond and Rajan (2009) and Fahri and Tirole (2009). 


\section{Close Some Banks at Date 0}

If there is insufficient liquidity for all banks to survive the liquidity shock, then all will be run and all will fail if each waits until date 1 to sell assets. There might be sufficient liquidity for some to survive if the others are closed and their assets taken "off market” (as in Proposition 4 (ii))

If banks are insolvent, the authorities can close them (if the banks are not “too big to fail”). To use solvency as a basis to close banks, the authorities will have to determine the value of assets, for which they will either need to generate a market price or they will have to hire experts to value the assets. ${ }^{15}$ They will also have to hold the illiquid assets in some holding entity (similar to the Resolution Trust Corporation) and sell them over time once the likelihood of the liquidity shock falls. Closure thus allows the authorities to remove the overhang of illiquid assets, and bring down required rates of return, but it does not absolve them of the need to value assets or inject subsidized liquidity at the costs described above (to finance the holding entity).

Difficulties arise when the banks appear solvent today and thus cannot be failed, but could become insolvent in the future - as in our model. Closure may not be an option for the "walking wounded”. It may also not be an option for the banks that are difficult to fail for a variety of reasons.

\section{Recapitalization if the shock occurs}

If the authorities are willing to infuse capital at the time the liquidity shock actually occurs, they could help when the problem is primarily one of fire sales leading to insolvency. Indeed, this is the situation in our numerical example. If, for instance, the authorities were committed to use taxpayer funds

\footnotetext{
${ }^{15}$ A market price will be sufficient to value assets held on the books so long as there are easily observable and verifiable characteristics that put the traded assets in the same equivalence class as the book assets - e.g., mortgage backed securities based on sub-prime mortgages originated by developer A in new development B in city C. If, however, there are still intrinsic differences between assets that require expertise (mortgages originated in the southside of the development have different default characteristics than those originated in the north side, and only south side mortgages are traded), then there is no alternative to hiring experts.
} 
to give the bank a gift of bonds of value 0.018 at date 1 that would pay off at date 2 , they could save the bank from being run. This would increase the date-1 security price above the "run” price, and increase lending at date 0 . Such an infusion could be thought of as "capital insurance."

A commitment to provide capital insurance which would inject just enough capital to allow the bank to survive will not induce the banker to sell securities early (because the banker knows his stake will be severely diluted even if the bank is bailed out, and thus his down side payoff will be very low, much as the situation where he is run). It does keep some assets off the market by preventing a run, and hence boosts securities prices, and thus lending. Indeed, the stress tests conducted by the U.S. authorities on 19 large banks in May 2009 might have been interpreted as a signal that the government would stand behind the banks regardless of their eventual loss levels. This eliminated the possibility of a large bank failure, and began the process of raising the prices of illiquid assets.

\section{Capital Requirements and Liquidity Requirements}

Thus far, we have examined ex-post interventions. A moderately capitalized bank holding illiquid assets can quickly become an undercapitalized bank if the risk of a liquidity shock increases rapidly. Of course, authorities could prevent levered illiquidity seeking banks from emerging in the first place by implementing very strict capital and liquidity regulations. As Diamond and Rajan (2001) argue, this could impose serious constraints on financial intermediation if carried too far. The appropriate level of ex ante regulations is clearly an important issue for further study.

\section{Related Literature, Alternative Explanations, and Evidence}

Some recent work has explained market freezes by appeals to asymmetric information, along the lines of the original insight of Akerlof (1970). Bolton, Santos and Scheinkman (2008) and Heider, Hoerova and Holthausen ( 2009) present interesting models of securities sales based on private 
information of existing banks about the value of their assets. For example, in Bolton, Santos, and Scheinkman (2008), long horizon investors cannot tell whether short horizon investors sell because they need liquidity or because they have adverse information about asset quality. This leads to a price discount, which deepens over time because the potential seller gets to know more about the asset. The seller thus has to decide whether to sell now in response to a liquidity need, or to attempt to ride out the crisis with the possibility of selling in the future at a much greater discount. There are both immediate trading equilibria and late trading equilibria, with the latter resembling our trading freeze. The clear difference in our model is the assumption of no information asymmetry within the set of buyers and sellers (and thus no increase in information asymmetry over time).

Acharya, Gale, and Yorulmazer (2009) show that borrowing freezes can arise when the information structure in the market shifts from one where the arrival of no news is good news (and the asset price goes up) to one where the arrival of no news is bad news (and the asset price goes down). In the latter situation, the borrowing capacity of a bank may be very low when it intends to roll over its borrowing repeatedly. The shift in information structure in the market can, therefore, cause lending to banks to dry up. Our paper explains, by contrast, why long term lending to industry, where there is no rollover risk, can also dry up.

Allen, Carletti and Gale (2009) present a model of freezes without asymmetric information, with limited liquidity as we assume, but without any risk of default. The market freezes there when there is ample liquidity but most of the liquidity risk is systematic rather than bank specific. The interbank market freezes because each bank wants to hold liquidity on its balance sheet rather than to borrow or lend it when nearly all banks will borrow or lend (rather than take offsetting positions).

The model of illiquid asset markets where prices are set by the quantity of liquidity in the market is closely related to that used in Bhatacharya and Gale (1987) and Allen and Gale (1998, 2003). This is 
related, yet somewhat different from the model of liquidity in Holmstrom and Tirole (1998), which relies on collateral value as the limit to liquidity of an asset, rather than limited purchasing power.

Our paper is closely related to Diamond and Rajan (2005), who model contagious bank failures due to limited aggregate liquidity. In their model, there is both individual bank risk about the proportion of their loans that generate liquid repayments quickly and aggregate uncertainty about the supply of liquidity. The potential failure of enough banks forces banks to call in bank-specific loans. Banks choose to increase interest rates to attempt to attract deposits from other banks, and this can bring down all other banks when liquidity is too low. The model assumes that the deposit market is competitive and that all assets, including bank deposits and short-term debt, must offer the same return as the loans that banks make. The model we present in this paper has similar features, but the limited liquidity influences banks only through prices of the financial security, rather than through the rates needed to attract scarce deposits. The effect of limited liquidity on the price of banks' financial security affects the rate of return anticipated in the market over time, and thus lending.

Our paper is also related to Shleifer and Vishny (2009), where banks expand and contract lending based on their ability to securitize loans in a sentiment-driven market. In their model, parameters are assumed such that banks would not want to hoard cash in order to buy assets when market sentiment falls. This then drives the pro-cyclicality of lending. However, banks would hoard securities and not sell them at such times, in anticipation of a recovery in prices. Our rationale for why banks hoard securities is different, since there are buyers in our market who are not infected by negative sentiment. The reason in our model is that banks prefer the higher return they get conditional on survival by holding on to the asset, to the lower unconditional return they get from selling. While sentiment in their model is analogous to liquidity in ours, the primary difference in implication is that in our framework, the authorities could make a difference by various forms of liquidity infusion. Of course, to the extent that liquidity infusion affects sentiment in un-modeled ways, this difference would diminish. 
Finally, our paper is related to Phillipon and Schnabl (2009). Unlike our paper, they treat the problem of credit contraction in a crisis as primarily due to a traditional long-term debt overhang caused by risky bank debt as in Myers (1977). Our focus on the institutional overhang of illiquid assets held by short-term debt financed institutions and implied illiquidity seeking is quite different from traditional overhang.

Our paper has implications for the world financial crisis of 2008-2009. Anecdotal evidence does seem to suggest that trading slowed in mortgage-backed securities as the possibility of liquidity shocks increased. Of course, bank lending also slowed, even to highly rated borrowers (Ivashina and Scharfstein (2009)).

The most obvious alternative explanation is one related to bank regulatory capital - that banks were trying to preserve book capital, and they would have been reluctant to sell securities that were heavily discounted in the market relative to what they were carried on the books for. According to the book capital explanation, the securities that had the greatest divergence between their book value and their market value would be the ones that banks would be reluctant to sell (and that they would move to the "held-to-maturity" account). Our model, by contrast, would suggest that the securities most exposed to liquidity risk would be the ones that the weak banks would be most reluctant to sell. Empirically, though, the securities whose market value diverges most from book value in a liquidity crisis may be the ones most exposed to liquidity risk, so these explanations are not easy to tell apart.

The book capital explanation would, however, suggest weak banks would not have strong incentives to add to their existing holdings of illiquid assets. Our model, by contrast, would suggest they would have an incentive to “double-up”, including by increasing leverage. There is some anecdotal evidence consistent with this. The Economist (February 27 , 2010) cites an ABN Amro executive who claims that the giant U.K. bank, Royal Bank of Scotland (RBS), got into trouble after its acquisition of Dutch bank ABN Amro because “RBS, desperate for profit and capital, insisted ABN’s risky credit 
trading positions be kept open—and some be increased. "RBS decided to take a massive punt,” he says.” More systematically, He, Khang, and Krishnamurthy (2010) show that over the period they examine, even while hedge funds and broker-dealers (typically investment banks) were reducing their holding of (illiquid) securitized assets by approximately $\$ 800$ billion, insured commercial banks were increasing their holdings by close to $\$ 550$ billion. At the same time, even while the rest of the industry appeared to be reducing leverage, banks increased leverage from 10 to between 20 and 32. He, Khang, and

Krishnamurthy argue that the likely explanation is commercial banks had easier access to funding because of help from the government - though absent the debt overhang incentives, it is less clear why banks would increase their holdings of illiquid assets rather than increasing lending substantially. Moreover, Huizinga and Laeven (2009) suggest mortgage-backed securities as a share of bank assets were increasing even before the panic-induced expansion in government lending support. Our model offers a reason why illiquid assets were more attractive, even without government aid.

\section{Conclusion}

Our paper explains why potentially distressed levered institutions may want to take large bets on illiquid assets simply because they see the marginal cost of the additional illiquidity as small. In this, our paper offers a rational explanation for why some institutions may largely ignore the probability of a liquidity crisis (see Gennaioli, Shleifer, and Vishny (2010)). Credit is unlikely to flow freely unless the problem of institutional overhang is dealt with - unless the solvency of illiquid institutions is assured, or the illiquid assets they hold are moved to entities that will not unload them quickly. The task of the authorities is to facilitate such a clean-up at minimum cost to the taxpayer. We have suggested some possible interventions that could be effective. More work is clearly needed to understand the links between solvency, liquidity, and lending better. 


\section{References}

Ackerlof, George, (1970), “The Market for Lemons: Quality Uncertainty and the Market Mechanism,” Quarterly Journal of Economics, 84 (3):488-500.

Acharya, Viral, Douglas Gale, and Tanju Yorulmazer (2009), “Rollover Risk and Market Freezes”, working paper, Federal Reserve Bank of New York.

Acharya, Viral, Hyun Shin, and Tanju Yorulmazer (2009), "Endogenous choice of bank liquidity: the role of fire sales," Bank of England working papers 376, Bank of England.

Adrian, Tobias and Hyun Shin (2008), “Financial Intermediary Leverage and Value at Risk”, Federal Reserve Bank Staff Reports 338.

Allen, Franklin and Elena Carletti, 2008, “The Role of Liquidity in Financial Crises”, 2008 Jackson Hole Conference Proceedings, Federal Reserve Bank of Kansas City, 379-412.

Allen, Franklin, Elena Carletti and Douglas Gale, 2009, “Interbank Market Liquidity and Central Bank Intervention,” working paper, Wharton School.

Allen, Franklin and Douglas Gale (1998), “Optimal Financial Crises,” Journal of Finance 1245-1284.

Allen, F. and D. Gale (2000a). “Financial Contagion,” Journal of Political Economy. 108, 1-33.

Allen, F. and D. Gale (2000b). "Bubbles and Crises, The Economic Journal, 110, No. 460: 236-255.

Allen, F. and D. Gale (2003). “Financial Intermediaries and Markets.” Econometrica, 72, 1023-1061.

Bhattacharya, S. and D. Gale (1987), Preference Shocks, Liquidity, and Central Bank Policy, in W.

Barnett and K. Singleton eds., New Approaches to Monetary Policy, Cambridge University Press, 69-88.

Bolton, Patrick, Tano Santos and Jose Scheinkman, Inside and Outside Liquidity, working paper, Princeton University, November 2008.

Brunnermeier, Markus (2008), “Deciphering the Liquidity and Credit Crunch 2007-2008”, forthcoming, Journal of Economic Perspectives.

Brunnermeier, Markus and Martin Oehmke (2009), “The Maturity Rat Race”, working paper, Princeton University.

Caballero, Ricardo, and Arvind Krishnamurthy, 2009, “Global Imbalances and Financial Fragility”, NBER working paper 14688.

Diamond, Douglas W. (1991), “Debt Maturity Structure and Liquidity Risk,” Quarterly Journal of Econoimcs, vol pp:.

Diamond Douglas W. and Raghuram Rajan, "Liquidity Risk, Liquidity Creation and Financial Fragility: A Theory of Banking”, 2001, Journal of Political Economy, vol 109, 2, 287-327. 
Diamond Douglas W. and Raghuram Rajan “Liquidity Shortages and Banking Crises.” Journal of Finance, 2005, 60, (2), 615-647.

Diamond, Douglas W., and Raghuram G. Rajan. 2009. "The Credit Crisis: Conjectures about Causes and Remedies." American Economic Review, 99(2): 606-10.

Diamond Douglas W. and Raghuram Rajan, 2009. "Illiquidity and Interest Rate Policy," NBER Working Paper 15197, National Bureau of Economic Research, Inc.

Farhi, Emmanuel and Jean Tirole (2009) "Collective Moral Hazard, Maturity Mismatch and Systemic Bailouts” NBER Working Paper 15138, National Bureau of Economic Research, Inc.

Gorton, Gary, 2009, “Information, Liquidity, and the (ongoing) panic of 2007”, NBER working paper 14649.

Gromb, Denis, and Dimitri Vayanos, 2002, Equilibrium and welfare in markets with financially constrained arbitrageurs, Journal of Financial Economics 66, 361-407.

He, Zhiguo, In Gu Khang, and Arvind Krishnamurthy, 2010, "Balance Sheet Adjustments in the 2008 Crisis”, working paper, Booth School, University of Chicago.

Heider, Florian, Marie Hoerova and Cornelia Holthausen, 2009, "Liquidity Hoarding and Interbank Market Spreads: The Role of Counterparty Risk,” European Central Bank working paper, February 2009.

Holmstrom, B. and J. Tirole, "Public and Private Supply of Liquidity,” Journal of Political Economy 106 (1998), 1- 40.

Huizinga, Harry and Luc Laeven (2009), “Accounting Discretion of Banks during a Financial Crisis”, IMF Working Paper, WP 09/207, International Monetary Fund.

Ivashina, Victoria and David Scharfstein, Bank Lending During the Financial Crisis of 2008, working paper, Harvard Business School.

Jensen, M.C. and W. Meckling, 1976, "Theory of the Firm: Managerial Behavior, Agency Costs and Ownership Structure, Journal of Financial Economics 3, 305-360.

Kashyap, A., R.G. Rajan, and J.C. Stein, 2002, "Banks as Providers of Liquidity: An Explanation for the Co-Existence of Lending and Deposit-Taking", Journal of Finance. 57 (1): 33-73.

Kondor, Péter, 2009, “Risk in Dynamic Arbitrage: The Price Effects of Convergence Trading,” Journal of Finance 64: 631-655.

Myers, S., 1977, The determinants of corporate borrowing, Journal of Financial Economics 5, 147-175.

Gennaioli, Nicolai, Andrei Shleifer, and Robert Vishny, 2010, Financial Innovation and Financial Fragility, mimeo, University of Chicago.

Phillipon, Thomas, and Philipp Schnabl, 2009, Efficient Recapitalizations, working paper, NYU. 
Shleifer, A. and R. Vishny, 1992, Liquidation value and debt capacity: A market equilibrium approach, Journal of Finance 47, 1343-1366.

Shleifer, Andrei and Robert Vishny (2009), Unstable Banking, working paper, University of Chicago.

Smith, Bruce, (1991)) “Bank panics, suspension and geography: Some notes on the 'contagion of fear' in banking,” Economic Inquiry, 24: 230-248.

Stein, Jeremy (2009), "Presidential Address: Sophisticated Investors and Market Efficiency,” Journal of Finance, Volume 64 Issue 4, Pages 1517 - 1548 

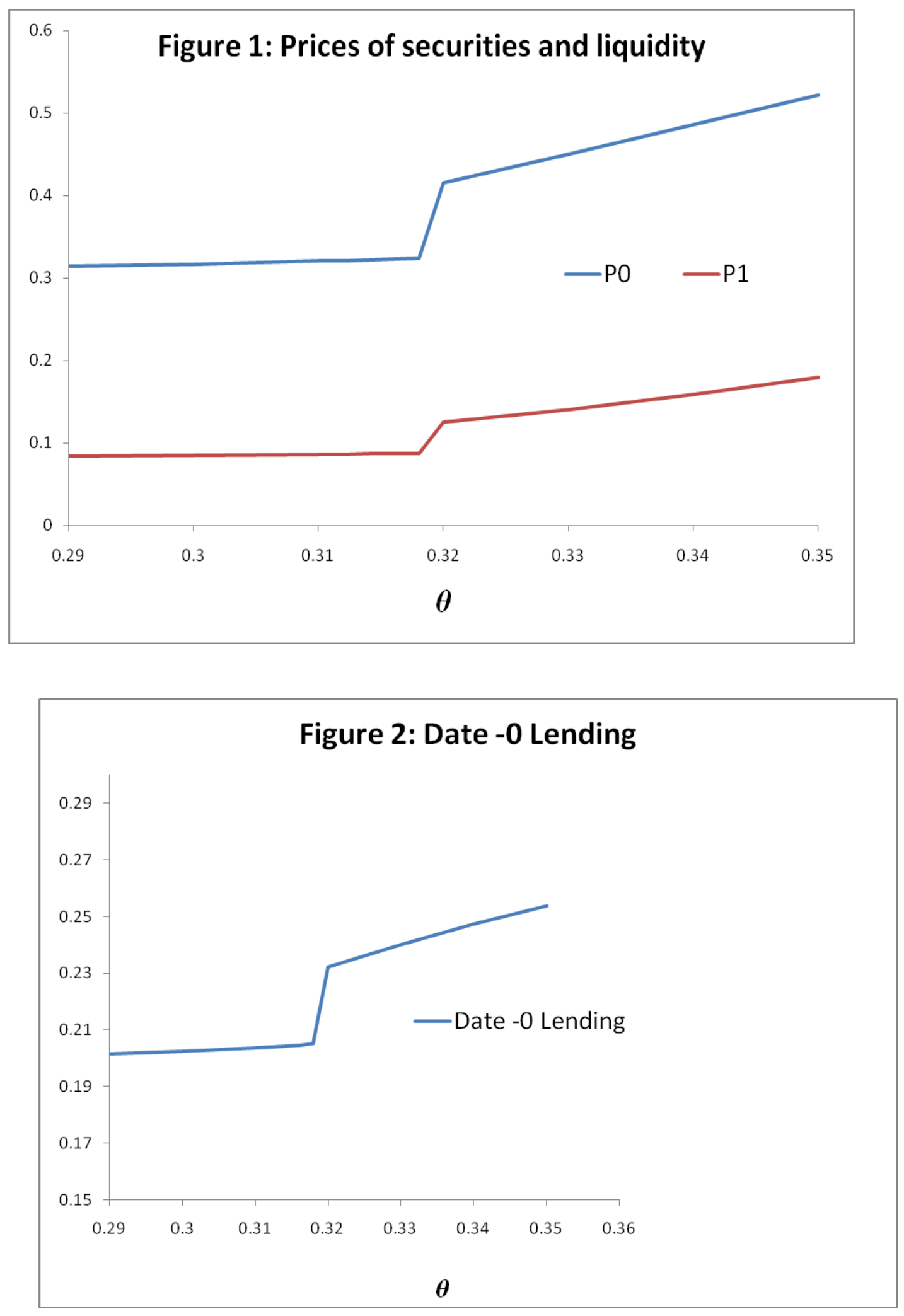


\section{Proof of Lemma 1;}

We sketch the proof when the change in parameters does not cause a change in whether the bank defaults or not. Incorporating such a change is straightforward. (i) Totally differentiating (1.3), we get

$$
\frac{d P_{1}}{d f}=\frac{D}{-(1-\beta) Z P_{1}+I^{\prime}\left(\frac{1}{P_{0}^{2}}\right) \frac{\partial P_{0}}{\partial P_{1}}} \text { which is negative since the denominator is negative. Similarly, we }
$$

can show $\frac{d P_{1}}{d D}<0$ and $\frac{d P_{1}}{d \theta}>0$. Since $P_{0}=\frac{1}{q \frac{1}{P_{1}}+(1-q)}$, lemma 1 (i) follows. (ii) Ceteris paribus, an increase in $q$ leads to a decrease in $P_{0}$. From (1.3), this must imply that $P_{1}$ will increase in equilibrium, since liquid buyers will lend less and store more cash. (iii) The condition for all sales to cease is that the bank ceases to be solvent. The solvency condition is given by (1.4), which on simplifying is $P_{1}\left[(1-\beta)\left(\frac{Z}{2}\right) P_{1}+\beta Z-D\right]>f D\left(1-P_{1}\right)-(1-\beta)\left(\frac{Z}{2}\right)$. This is clearly satisfied if $P_{1}=1$, so long as $D<Z$. As $f$ increases, $P_{1}$ falls, from lemma 1 (i). So the right hand side of the inequality increases, while the left hand side falls. Hence provided the bank fails for some $f^{R}$, it should fail for all $f>f^{R}$. The other conditions follow similarly. Q.E.D.

\section{Proof of Proposition 3}

The bank will take prices as given. If the bank is solvent, the expected value it gets from selling fraction $\eta_{0}$ of securities at date 0 to meet the liquidity demand at date 1 is

$$
\begin{aligned}
& q \delta^{i}\left[\beta\left(1-\eta_{0}\right) Z+(1-\beta) P_{1} Z-(1-f) D\right]+q\left(1-\delta^{i}\right)\left[\frac{\beta \eta_{0} Z P_{0}+(1-\beta)\left(\frac{Z}{2}\right)\left(1-P_{1}^{2}\right)}{P_{1}}+\beta\left(1-\eta_{0}\right) Z+(1-\beta) P_{1} Z-D\right] \\
& +(1-q)\left[\beta \eta_{0} Z P_{0}+\beta\left(1-\eta_{0}\right) Z+(1-\beta) Z-D\right]
\end{aligned}
$$


where $\beta \eta_{0} Z P_{0}+(1-\beta)\left(\frac{Z}{2}\right)\left(1-P_{1}^{2}\right)=f D$

The term in the first square brackets is the value of the bank conditional on the aggregate liquidity shock occurring and the bank also getting it, the term in the second set of square brackets is the value of the bank conditional on the aggregate liquidity shock occurring and the bank escaping being hit. - in which case it reinvests any cash, raised at date 0 from the sale of securities and at date 1 from the liquidation of loans, in securities at date 1 at the prevailing price, $P_{1}$. The term in the third set of square brackets is the value of the bank if the aggregate liquidity shock does not occur.

Similarly, we can write down the expected value of the bank if it does not sell securities at date 0 but instead sells securities at date 1 only if it faces the demand from depositors. This is

$$
\begin{aligned}
& q \delta^{i}\left[\beta\left(1-\eta_{1}\right) Z+(1-\beta) P_{1} Z-(1-f) D\right]+q\left(1-\delta^{i}\right)\left[\frac{(1-\beta)\left(\frac{Z}{2}\right)\left(1-P_{1}^{2}\right)}{P_{1}}+\beta Z+(1-\beta) P_{1} Z-D\right] \\
& +(1-q)[\beta Z+(1-\beta) Z-D] \text { where } \beta \eta_{1} Z P_{1}+(1-\beta)\left(\frac{Z}{2}\right)\left(1-P_{1}^{2}\right)=f D
\end{aligned}
$$

If the bank is indifferent between selling at the two dates, it must be the two expected values are equal. Equating the two expected values and recognizing that if the demand for liquidity has to be met on both dates so that $\eta_{0} P_{0}=\eta_{1} P_{1}$, we obtain on simplifying that $P_{0}=\frac{1}{q \frac{1}{P_{1}}+(1-q)}$. This means the date zero price the bank is willing to sell for, given an anticipated date 1 price, is independent of the bank's exposure to the shock, $\delta^{i}$. 
But if banks are insolvent conditional on the shock hitting (that is, if $\left.\beta Z P_{1}+(1-\beta)\left(\frac{Z}{2}\right)\left(1-P_{1}^{2}\right)-f D+\left[(1-\beta) P_{1} Z-(1-f) D\right] P_{1}<0\right), \delta^{i}$ does determine the size of the put option. Note that in this case, because its value conditional on experiencing the liquidity shock is limited to zero, the bank's expected value if it waits to date 1 to sell is $q\left(1-\delta^{i}\right)\left[\frac{(1-\beta)\left(\frac{Z}{2}\right)\left(1-P_{1}^{2}\right)}{P_{1}}+\beta Z+(1-\beta) P_{1} Z-D\right]+(1-q)[\beta Z+(1-\beta) Z-D]$

We want to find the value $P_{0}^{\text {Ask }}$ such that the bank's value if it sells enough at date 0 to meet the liquidity demand equals its value if it waits till date 1 to sell and enjoys the limited liability put. Equating, substituting $\beta \eta_{0} Z P_{0}^{A s k}=f D-(1-\beta)\left(\frac{Z}{2}\right)\left(1-P_{1}^{2}\right)$, and simplifying, we get

$$
P_{0}^{A s k}=\frac{1}{\frac{q \delta^{i}\left[\beta Z+(1-\beta) P_{1} Z-(1-f) D\right]}{f D-(1-\beta)\left(\frac{Z}{2}\right)\left(1-P_{1}^{2}\right)}+\frac{q\left(1-\delta^{i}\right)}{P_{1}}+(1-q)}
$$

If the bank is insolvent conditional on the liquidity shock, we know $P_{1}\left[\beta Z+(1-\beta) P_{1} Z-(1-f) D\right]+\left[(1-\beta) \frac{Z}{2}\left(1-\left(P_{1}\right)^{2}\right)-f D\right]<0$ (see (1.4)). So the denominator on the right hand side of (1.10) decreases in $\delta^{i}$, and $P_{0}^{A s k}$ increases in $\delta^{i}$. Q.E.D. 


\section{Proof of Proposition 4:}

(i)The date-1 interest rate, $\frac{1}{P_{1}}$, is determined by the condition that there be enough liquidity, after liquidating loans, to meet depositors needs. Provided the bank is solvent, the liquidity condition is

$$
(1-\beta) \frac{Z}{2}\left(1-\left(P_{1}\right)^{2}\right)+\left[\theta-I\left(\frac{1}{P_{0}}\right)\right]=f D
$$

Note that there is a unique $P_{1}$ that solves this, and $P_{1}$ is independent of how many securities are sold at date 0 , provided all buyer cash is not exhausted. This also means that regardless of how many securities are sold at date 0 , the date- 1 price of securities will be $P_{1}$ for that is the value of the marginal loan that the bank can avoid liquidating if it sells a security at date 1 instead. This means the date- 0 price of securities is $P_{0}=\frac{1}{q \frac{1}{P_{1}}+(1-q)}$, so long as

$$
\beta Z \eta_{0} P_{0}<\left[\theta-I\left(\frac{1}{P_{0}}\right)\right]
$$

It is then clear that the bank's solvency can be improved by forcing it to sell more securities at date 0 . The solvency condition is

$$
(1-\beta) P_{1} Z . P_{1}+(1-\beta) \frac{Z}{2}\left(1-\left(P_{1}\right)^{2}\right)+\beta Z\left(\eta_{0} P_{0}+\left(1-\eta_{0}\right) P_{1}\right) \geq(1-f) D P_{1}+f D
$$

and the left hand side clearly increases in $\eta_{0}$ (because $P_{0}>P_{1}$ ). Hence (i).

(ii) Once, however, the date-0 sales account for all the cash with buyers, additional sales will come at a reduced price. We need to see how $\beta Z\left(\eta_{0} P_{0}+\left(1-\eta_{0}\right) P_{1}\right)$ varies with $\eta_{0}$ when 
$\beta Z \eta_{0} P_{0}=\left[\theta-I\left(\frac{1}{P_{0}}\right)\right]$. Totally differentiating the equality constraint, we

get $\beta Z\left(P_{0}+\eta_{0} \frac{d P_{0}}{d \eta_{0}}\right)+I^{\prime}\left(\frac{-1}{P_{0}^{2}}\right) \cdot \frac{d P_{0}}{d \eta_{0}}=0$. Therefore $\frac{d P_{0}}{d \eta_{0}}=\frac{-\beta Z P_{0}}{\beta Z \eta_{0}-\frac{I^{\prime}}{P_{0}^{2}}}$, which is negative because

$I^{\prime}$ is negative. Differentiating $\beta Z\left(\eta_{0} P_{0}+\left(1-\eta_{0}\right) P_{1}\right)$ with respect to $\eta_{0}$, and substituting for $\frac{d P_{0}}{d \eta_{0}}$, we

get $\beta Z\left(P_{0}-P_{1}-\eta_{0} \frac{\beta Z P_{0}}{\beta Z \eta_{0}-\frac{I^{\prime}}{P_{0}^{2}}}\right)$, which is clearly negative if $I^{\prime}$ is small. Intuitively, once the cash

constraint becomes binding additional date- 0 securities sales will depress the date- 0 price, not raise the cash with buyers if $I^{\prime}$ is small, and only reduce the value of securities carried over to date 1 , hence reducing the bank's value. This means that if there is no $\eta_{0}$ such that (1.12) and (1.13) are satisfied, the banks cannot all be made solvent by date-0 sales.

It is possible, though, that a subset of the banks could be made solvent if they are allocated all the date-0 liquidity. If $\gamma$ of the banks are saved, it must be that they consume all the cash at date 0 at the date-0 price $P_{0}=\frac{1}{q \frac{1}{P_{1}}+(1-q)}$, hence

$$
\gamma \beta Z \eta_{0} P_{0}=\left[\theta-I\left(\frac{1}{P_{0}}\right)\right]
$$

Note that following reasoning similar to what we laid out above, once date-0 buyer cash is exhausted, the bank would not attempt to sell more securities at a price lower than $P_{0}=\frac{1}{q \frac{1}{P_{1}}+(1-q)}$. Furthermore, the $(1-\gamma)$ failed banks will liquidate all their loans (and pay their depositors), and sell all their securities in the market at date 1 at price $P_{1}$. So the cash available with buyers (or with solvent banks that have raised more than they need at date 0 to meet liquidity demand at date 1 ) is used to pay off solvent bank 
depositors (net of what solvent banks can raise by liquidating loans) and buy securities from failing banks. This implies

$$
(1-\gamma) \beta Z P_{1}+\gamma\left(f D-(1-\beta) \frac{Z}{2}\left(1-\left(P_{1}\right)^{2}\right)\right)=\left[\theta-I\left(\frac{1}{P_{0}}\right)\right]
$$

Finally, the solvency condition for the solvent banks is unchanged and is

$$
(1-\beta) P_{1} Z . P_{1}+(1-\beta) \frac{Z}{2}\left(1-\left(P_{1}\right)^{2}\right)+\beta Z\left(\eta_{0} P_{0}+\left(1-\eta_{0}\right) P_{1}\right)=(1-f) D P_{1}+f D
$$

Clearly, the maximum number of banks can be saved if the date-0 liquidity is fully and equally divided amongst the saved banks such that the solvency constraint is just met. Hence conditions (1.15) and (1.16) are equalities. (iii) follows immediately.

(iv)Failed banks sell all their securities while solvent banks sell only a fraction of their securities. Therefore, given the fixed supply of buyer cash, increasing the fraction of solvent banks will raise the date- 1 price, and by buyer arbitrage, the date- 0 price. 